\title{
VOS YA SABES A QUE MONSEÑOR YO ME REFIERO
}

Pastor de penas sin cuento apacentaste desdichas las congregastes todas las llamaste por sus nombres una a una

hasta quedar quebrantado abrumado hundido aniquilado por ellas.

"(Ya sabía que asi iba a ser mi muerte pues aquí uno termina en cualquier parte en cualquier minuto de esta espera.

El quid está en darle la cara en hacerle frente para caer como cae el valiente y no quedar -estatua de salpetrificado en una huida)".

Con tu cayado calladamente muchas veces dialogabas con la sangre te internabas sin saberlo quizás hasta el boquete hasta la cueva de la más honda de todas las heridas y sallas ileso -dolido pero ileso-

\section{Rafael Rodríguez D.}

para emprender de nuevo tu marcha cotidiana.

Recogiste del viento las palabras y las quejas las pusiste en tu bolso y las lanzaste luego como dardos contra los paredones oscuros antahiones.

Pero el conjuro fue demasiado poderoso el aquelarre no te fue propicio. Te asediaron las brujas pese a los exorcismos te condenaron a la hoguera los druidas de este circulo de fuego.

La posesion la histeria te fue cortando todas las retiradas hasta tapar el mas minimo resquicio y te dejaron solo asomado a una claraboya donde todo el mundo pudo verte y todo el mundo pudo tantear la punteria hasta que alguien dio finalmente en el blanco

"(En la otra vida -en esta vida que ya habitono existe la luz como creía.

La misma tiniebla me circunda 
y me amenaza.

Pero hay un vinculo fuerte que me ata

a las palabras que un día

fueron norte

y fueron vida.

Por eso vivo en el canto

que el pueblo entona

a los caldos

salgo a bailar resplandeciente

en las antorchas

me doy por satisfecho

estoy salvado.

Es el descanso merecido

del guerrero)"

De nuevo

te has ido quedando solo

Monsefior.

Tus pares se aglomeran

se meten debajo

de las mesas

para comer las migajas

que tiran desde el cielo

los de arriba.

Pellcula que ya no se repite te quedaste incunable

sin escuela.

Porque quieren echarle tierra

a tu memoria

y quizás lo están consiguiendo

en parte

porque tu nombre

se va filtrando como el agua

sobre tierra arcillosa.

Las manos de tu pueblo

se están quedando secas

ya casi no hay lágrimas

que doren las mejillas.

Para colmo de males tus pares se empeñan

en condenar procesiones

que podrian atraer

lluvias abundantes

cosechas

frutos opimos.

"(No me importa

que griten

contra el tiempo.

No me importa

que entierren mi retrato

si está germinando la semilla

si la selva que talaron

se está poblando

de retoños.

Que sigan fumigando

regando insecticidas

envenenando el aire

el agua

las palabras

porque en este campo abonado

ya nadie detiene

las cosechas que vendrán

con las nuevas estaciones.

Empeñé mi palabra

la of reci como prenda.

Como Humahpú

prometí que florecería

el tallo de la milpa.

Y lo estoy logrando pese a todo)"'.

Adios,

guerrero de la tarde.

Sumite ya en el descanso

de la noche.

Estate tranquilo

satisfecho

porque este lago

es casi un hervidero

es un volcán

una tormenta.

$Y$ en el rayo, en la centella

está volviendo a brillar

como un dardo tu palabra.

Quizás esa sea la luz

que despiden los tesoros

el fuego fatuo

de los cementerios

la piedra del rayo

que expulsan las culebras.

Dormite granquilo

en tu tiniebla

Reposá con la inmensa masa

de los pobres

para quienes no hubo una cruz

para marcar su tumba.

Quedate junto a ellos

alentálos al descanso

pero tambien a la lucha

que debe subir como jugo 
de la tierra

por las ralces del hombre

que combate

hasta convertírsele en savia

en sangre nueva.

\section{Adios}

montañista de tristezas

apacentador de luceros.
No olvides tu cayado para guiar a los perdidos y segul desde la sombra acompantando

nuestra espera.

10 de febrero de 1983. 